\title{
THE SEARCH FOR THE PAST: THE ROLE OF AZTEC MYTHOLOGY IN LA REGIÓN MÄS TRANSPARENTE
}

Shirley A. Williams

The use of Aztec imagery and symbols evoking the indegenous past is one of the most striking elements of style in Carlos Fuentes' novel La región más transparente. The author's use of these images is, of course, stylistically appropriate in a work which explores the many facets of "la mexicanidad," but Fuentes' use of Aztec mythology has a far more important function than simply creating an exotic and uniquely Mexican atmosphere for his national epic. It is the thesis of this paper that Fuentes' use of Aztec mythology is intimately related to the development of the novel's central theme.

The use of primitive imagery centers around the figures of the ancient Teódula, the Widow Moctezuma, and her son Ixca Cienfuegos. Teódula and Cienfuegos clearly incarnate the mythology and values of Indian Mexico. When we first see the widow, she is enacting the rites for the dead, a function which symbolically links her to the past. Her thoughts all lead to the past and remembrances of her youth establish a vision of the mythological past as an "edad dorada" with which the imperfect present must always be compared. Implicit in this idealized vision are the concepts of innocence and perfect union with nature which always characterize the myths of creation:

- Luego por allá hay mucha selva, y culebras color de vidrio, y yo salía a pasearme con mis joyas. Quería hacerme una falda de fiesta con las pieles de las serpientes pero cuando salía a pasearme todas las bestias se quedaban asombradas del ruido y la luz de mis joyas, y era como cosa de encantamiento como se apartaban y yo ya no podía ponerles trampas a las inocentes. Pero allá las joyas eran, ¿como te diré?, un pedazo de toda la luz y el color, no eran cosas aparte para esconder o disfrutar a solas, hijo. Aquí en México es donde se me ocurrió que podrían robármelas, o que las joyas ya no eran de todos, sino sólo mías. ${ }^{1}$

Teódula voices the need to return to this sense of cosmic unity. After propitiating the Gods, man could then live in harmony with nature, and like the widow in her youth, enjoy innocent sexual strength. But to regain this unity, sacrifice is necessary "... un sacrificio diario, un alimento diario para que el sol iluminara, corriera y alimentara a su vez" (p. 254).

The idea of sacrifice is a complex concept embodying several key ideas. Firstly, the Aztec sacrifice links the present to both the past and to the future. The sacrifice is enacted according to ritualistic formulas established by past tradition, yet it points towards the future. Indeed, its purpose is to ensure the future continuation of life. Secondly, sacrifice implies the subordination of the individual to the collective. According to Aztec legend, the sun was created when a leprous god cast himself into the braizer as a sacrifice. He rose from the blazing coals changed into a star. ${ }^{2}$ This must 
continue, for "- el mundo no nos es dado... - tenemos que recrearlo. Tenemos qu mantenerlo" (p. 251).

Teódula charges her son, Ixca Cienfuegos, with the task of procuring the sacrific which will reinstate the world of the Indian past. Cienfuegos is a complex figure, botl character and symbol. ${ }^{3}$ The elaborate metaphors of flowers, feathers, eagles, sacrifici obsidian knives, and sun and moon imagery, which are always present in his interio monologues serve to remind the reader of his symbolic function as the representative 0 the primitive past. This drive towards the past is, in addition, his chief thematic function He stimulates all of the other characters to remember, to re-examine the past. His searc for the sacrificial victim who would provide the link to the past unifies the novel an provides the only point of continuity between diverse characters and episodes.

The world of cosmic unity Teódula and Cienfuegos envision is clearly not the world of modern Mexico City, a city "... deforme y escrofulosa, llena de jorobas de cemento hinchazones secretas..." (p. 215) where the only nature its people know is "Esta lluvia ocasional y contaminada" (p. 249) that never reaches the soil. The contrast between the ideal world of the past and the realities of life in present day Mexico City can be seen in the lives of all of the central characters, but is especially evident in the business magnate Federico Robles, who is in many ways Ixca's antithesis. Having risen from a cornfield in Michoacán to a position of power through the Revolution, Robles denies his Indian origin and refuses to acknowledge the past: "el pasado no existe... México es otra cosa después de la Revolución. El pasado se acabó para siempre" (p. 266). ". . Aquí hay que mirat hacia el futuro" (p. 265). Far from the mythological ideal of the individual sacrificing himself for the collective, Federico represents selfishness in the extreme, maintaining that because of what he has suffered in the Revolution, he has the right to take whatever he wants. He lives an incomplete, fragmented life separated from both nature and society. Our first view of him looking over the city from his office window while he himself remains encased in glass, isolated, privileged, sounds the keynote for his characterization. His marriage of convenience to Norma Larragoiti is joyless, and sterile. It is only in his relationship to his blind Indian mistress Hortensia that Robles discovers the freedom of an instinctive sexual relationship that becomes his source of strength, and provides him with a tenuous link to nature and the cosmic unity implicit in Teódula's vision.

Ixca's search for a victim leads him to Norma and Federico. Rumors he starts lead to the collapse of Robles' financial empire and precipitate a confrontation between Federico and Norma. Norma refuses to accept their ruin; the two argue violently, and as Robles leaves the house, overturning tables and furnishings in his fury, he inadvertently starts a fire which destroys both Norma and his remaining material possessions. This fire scene occupies a pivotal position within the work, for after the fire both Robles and Cienfuegos change dramatically. The full significance of this change, however, becomes apparent only upon realizing the fire's symbolic importance in Aztec mythology.

The Mexican equivalent of our century was a time period of 52 years. At the close of this period, the fate of the universe was in doubt. When the sun set on the last day of the century, no one knew whether it would rise again or whether the world would end amid the cataclysms which, according to Mexican myth, had destroyed the four previous worlds or "suns." The ceremonial rite of the new fire was performed at the end of each 
century in an attempt to insure the continuation of the cosmos. Jacques Soustelle provides the following description of the ceremony:

In all the cities and throughout the countryside the fires were put out; the close-packed crowds, filled with intense anxiety, gathered on the slope of Uixachtecatl, while on the mountain top the priests watched the Pleides. The constellation mounted towards the zenith: but would it go on? Or would it stop, and would the hideous monsters of the end of the world come swarming out? The astronomer priest made a sign: a prisoner was stretched out on the stone. With a dull sound the flint knife opened his chest and in the gaping wound they spun the fire-stick, the tlequauitl. The miracle took place and the flame sprang up, born from this shattered breast; and amid shouts of joy messengers lit their torches at it and ran to carry the sacred fire to the four corners of the central valley.

César A. Sáenz further notes the emphasis on renewal which surrounded the ceremony of the new fire:

Una vez producido el Fuego Nuevo significaba que el mundo no había sido destruido al finalizar el 'siglo,' que el sol seguiría saliendo y las Pleyades continuarían su curso por el firmamento. Los habitantes de cada pueblo renovaban sus alhajas, vestidos, esteras, y todos los utensilios de sus casas eran nuevos en señal del año que comenzaba. Rompían sus objetos domésticos de barro. ${ }^{5}$

Other aspects of Aztec mythology associate fire with creation and rebirth. The fire god Xiuhtecuhtli was also the lord of life and time, and fire was often seen as a creative force. Burland comments:

There appears to have been some vague feelings among the Mexicans that death and life in the underworld was not the end of the soul. At some point or other it was taken to the fire, and escaped through the fire into life; but this was not specifically set out in any document, only suggested in some of the poems. ${ }^{6}$

Throughout the Aztec religious writings fire is seen as the life in all things. The fire which destroys is also the spirit which creates anew.

It is clear that Fuentes intends for the fire scene to act as a turning point in his novel, and that he invests fire with some of the symbolic significance of the ancient rituals. Throughout the novel Robles, with his futuristic ethic, has been one of Ixca's chief ideological opponents. Cienfuegos attempts to understand him, to penetrate his essence in order to destroy him. True understanding escapes him, but he intuitively realizes that either he or Robles must perish:

¿Cuál era este origen, verdaderó origen, de Robles? Ixca, detenido en la esquina de Madero y Palma para encender un cigarillo, sabía que debió ser de tal manera escueto y sencillo que él, Ixca, jamás lo entendería. Que la vida oscura y marginal que Hortensia Chacón le ofrecía era un sustituto, a lo sumo un reflejo intermedio de ese encuentro original, que el ejercicio de poder descrito por Librado Ibarra (y también, de otra manera, por el propio Robles) no era sino una fuga, que a la vez sunonía una constitución, de ese mismo origen escondido. Y en el destino de ese origen, sintió en ese momento Ixca Cienfuegos, allí se libraría la batalla, allí triunfarían, o la nueva imagen de Robles, o Cienfuegos y Teódula. . . (pp. 346-47). 
Under Ixca's prodding, Robles begins remembering his past immediately aft realizing his ruin. This stimulus to remember has a purgative function. It prepares him to face the realities of his life without his habitual excuses and self justifications. Then before the fire:

... sintió en el centro del cuerpo, un afán nuevo, de asco y destrucción y nuevo encuentro, que sin saberlo había germinado en las voces, los recuerdos y las horas solitarias del última día (p. 384).

The fire which follows Robles' meditation destroys all of his material possesions, and takes Norma's life. Old Teódula casts her ancestral jewels into the blaze murmuring: "- Así lo queríamos los dos, Ixca hijo ... - Te lo dije; ellos andan escondidos, pero luego salen. A recibir la ofrenda y el sacrificio" (p. 396). The destruction of Robles household goods and Norma's sacrificial death in the flames have an obvious parallel to the sacrifices connected with the ceremony of the new fire. Indeed, it seems that one of Ixca's principal functions in the novel is merely to act as a catalyst for the flame that consumes Robles' old life. Even his name binds him symbolically to the fire rites.

Once the ritual is completed, the two men undergo dramatic reversals. Ironically Cienfuegos, who had hoped to re-establish the past and resurrect the indigenous strength he represents, appears at the novel's end as an entirely defeated man. Even his physical appearance mirrors his collapse, and he can only continue the now futile and meaningless search for a sacrifice by almost causing Rodrigo Pola's death before he vanishes in mists at the novel's end, absorbed by the city. Robles, on the other hand, undergoes a type of rebirth. After the fire as he drives through the city, "... se sintio al final de un largo viaje..." (p.419). After his remembrances of Frolián and Feliciano Sánchez, he is now able to identify with Gabriel and all the nameless, faceless masses of Mexico's poor:

Más allá de sus huesos y de su sangre, en las vidas de otros que en ese minuto de humillación y carne rendida eran su propia vida, en las vidas mudas que lo habían alimentado, sintió la razón verdadera. .. (p. 422).

He then returns to Hortensia and holding hands they remain:

Los dos sentados, con la vida entre los dedos, sin hablar. Parte de esa sangre era de esclavo, de señor sometido, de vida que ha olvidado para siempre su vida. El hombre y la mujer morenos, vestidos con las ropas de la civilización occidental, solo tenían esos dedos para decirse que eran iguales, y otros. Una ternura común anticipaba, a través de ese contacto, un reconocimiento. No hablaban.

Federico sintió que el sol de ese día llegaba a su punto más alto, desierto de color, llagado y suntuoso. Sabía que aquí, entre los dedos de Hortensia Chacón, iba a saber (p. 424).

This is the last vision we have of Federico. The novel's concluding third section contains only one highly significant reference to him. Rodrigo Pola notes: "- Del que se perdió todo rastro fue Robles. ¿Tú sabes que fue de él? Me dijeron que se había vuelto ${ }^{a}$ casar -." And Ixca responds: "- Sí, se casó. Vive en el Norte; creo que tiene tierras y cultiva algodón. Creo que en Coahuila. Tiene un hijo" (p. 441). 
These few lines trace the possibility of an optimistic future for Robles. This note of optimism is conspicuously absent in the lives of the other major characters. Sommers notes:

In Where the Air is Clear, the experience of defeat is decisive for all of the leading characters. Ixca's attempt to regain the past is ultimately fruitless. The idealism of Zamacona meets senseless death. Rodrigo admits finally that he has forsaken his cherished personal goals. For Robles, defeat proves to be purgative and restorative, and of all the destinies, his appears to come to terms with defeat, as it impels him to rearrange his outlook and reorder his existence. The defeat which closes the doors of the capitalist world to him seems to be followed at the novel's end by a search for a new life. $^{7}$

The new life that opens to Robles is based, paradoxically, on a return to many of the mythical ideals Ixca Cienfuegos advocated. Having been led my memory back to his origins, and having accepted these origins, he returns to Hortensia as she had predicted he would. The two then leave Mexico and return to the land. Again the open and innocent sexuality he had enjoyed with Hortensia provides the key to Federico's re-entry into a life in union with the archetypal forces of nature; the son they conceive is the symbol of this new accord. Robles, then, represents the only possible solution for the problems of Mexico posed in the novel. Ixca's quest to recapture the past is as futile as Robles' original denial of the past. Life is neither past nor future, but a present which demands cognizance of both. In his new life, Robles seems to have come close to the balance recommended by the idealistic Zamacona: "El progreso debe encontrarse en un equilibrio entre lo que somos y nunca podremos dejar de ser y lo que, sin sacrificar lo que somos, tenemos la posibilidad de ser..." (p.61). It is most fitting, of course, that Robles symbolize the future for Mexico, because of all the characters, only Robles incorporates nearly all elements of the Mexican experience: the Indian, the Revolutionary, and the Capitalist - Nouveau Riche. His future can thus validly symbolize that of his nation. And it seems clear that in the character of Robles, Fuentes leaves a note of hope for the future.

In summary, Teódula and Ixca's efforts to re-establish the world of the primitive past are fruitless. Yet their presence within the novel provides the stimulus which forces Robles to examine the past, and to acknowledge his debt to it. And it is the Aztec mythology Cienfuegos voices that provides Fuentes with the symbolism of the ancient fire rites which he uses to underscore the destruction and subsequent rebirth of Robles, which is the novel's central theme.

\section{Department of Languages}

The Ohio State University

(Lima Campus), USA 


\section{NOTES}

${ }^{1}$ Carlos Fuentes, La región más transparente (México: Fondo de Cultura Económica), p. 202. All succeeding quotations refer to this edition.

2 Jacques Soustelle, Daily Life of the Aztecs, Trans. Patrick O'Brien (New York: MacMillan, 1962), p. 96.

${ }^{3}$ For a complete discussion of the role of Ixca Cienfuegos as character-symbol see Joseph Sommers, After the Storm (Albuquerque: The University of New Mexico Press, 1968), pp. 99-137.

${ }^{4}$ Soustelle, op. cit., pp. 101-102.

5 César A. Sáenz, El fuego nuevo (México: Instituto Nacional de Antropología e Historia, 1967), p. 19.

${ }^{6}$ C. A. Burland, The Gods of Mexico (New York: G. P. Putnam's, 1967), p. 89.

7 Joseph Sommers, After the Storm, p. 137. 